\title{
Understanding our value; assessing the nature of the impact of library services
}

David Bawden, Andrew Calvert, Lyn Robinson, Christine Urquhart, Colin Bray and John Amosford

\begin{abstract}
This paper reports an approach to assessing the nature of the impact and benefit of library services, based on the concepts introduced in Urquhart's Value Project for healthcare information services. Two studies are described and compared. A project in the City of London public library service examined the benefits obtained from specific information requests. A project in several public library services in South West England examined the value obtained from the borrowing and reading of books, linking this with categories of learning objectives. These studies showed the promise, and also the difficulties, of adapting existing impact frameworks to understand the nature of the impact and value of library services.
\end{abstract}

\section{Introduction}

The evaluation of library and information services is a complex task, because there are a number of rather general ways in which it may be approached. For recent overviews, see Matthews (2007), Crawford (2006), Booth (2004), and Bawden, Petuchovaite and Vilar (2005). For higher education libraries in the UK, Sconul's VAMP project aims to help academic library and information services

\section{Authors}

Professor David Bawden is based in the Department of Information Science, City University. His research interests include knowledge organisation, domain analysis, and the foundations of library and information science. Andrew Calvert was a postgraduate student in the Department, and the paper discusses his dissertation research. Lyn Robinson also works in the Department, as Director of the Information Studies scheme, as well as directing courses for Aslib. Dr Christine Urquhart's research interests include impact studies, particularly in the health library sector, and she has directed several national and local evaluation studies. Colin Bray is Adult Lending Services Manager (Exeter). John Amosford works for Devon County Council, and was closely involved in the Reading - a difference survey also discussed in the article.

Email: d.bawden@soi.city.ac.uk

Received 27 July 2009

Accepted 26 October 2009 
assess their impact, as well as provide an assessment of their value, through the contibution by made library staff to the work of their higher education institution (Creaser, Conyers and Lockyer, 2007). This attempt to evaluate the 'true benefit' or 'real value' which library / information services confer on their users, as distinct from the more common 'performance indicators' approach (Poll and Boekhorst, 2007) is a challenge. There has been more interest in developing toolkits and frameworks to help other libraries learn from the experience of other libraries when assessing their own value to their users and their communities.

This paper reports impact assessment in two rather different circumstances: an assessment of the value of the use of material in the City of London public library service for answering specific information requests; and a study in public library services in the South West of England, examining what users felt they had gained from books which they had borrowed. By comparing the approaches used to develop the frameworks in each study, and the findings, we derive some recommendations for impact studies in public libraries, and suggest where the values for the customers may be found.

The recent literature indicates trends towards greater synthesis of evaluation findings as well as toolkit support for performing impact studies. For example, Imholz and Arns (2008) report on the Americans for Libraries Council review of library evaluation studies. The toolkits (detailed below, see also Markless and Streatfield, 2006) encourage some standardisation in the type of questions asked, to help in comparison and synthesis of findings.

\section{Background overview of value assessment}

This has generally been approached in three general ways: assessment of monetary value; assessment of impact; and assessment of the nature of the benefit provided.

Assessment of monetary value is in many ways the 'holy grail' of service evaluation, since it provides a justification for the continuation, or expansion, or services in terms acceptable to managers and funders. In an ideal world, each library service would like to justify its activities by demonstrating its 'true worth' to its patrons, by showing its value to them in monetary terms. This could then be compared with the known costs of the service, to produce a true cost-benefit ratio.

In practice, however, such a task is very difficult. Although the costs of the service may be determined accurately, its monetary benefits are notoriously difficult to quantify. Ultimately this is a reflection of the difficulty of putting a monetary value on information itself, since its value can only be determined when, and if, the consequences of the availability and use of information are known, and can be compared with the situation where the information was not available (Yates-Mercer and Bawden, 2002).

As a surrogate for this full understanding, a variety of methods under the general heading of 'contingent valuation' or stated preference may be used. These have been derived as a means of assessing the value of non-market (freely provided, or semi-private, but non tradable) goods and services, by assessing their users' 'willingness to pay', and have been applied to library services in a number of 
studies; see Chung (2008) for a recent review and critique. Three examples will give a feeling for this method.

Morris, Sumsion and Hawkins (2002) attempted to estimate the value of the borrowing of books from British public libraries, by asking library patrons to estimate the value of the benefit which they had obtained from books borrowed, and how much they would have been willing to pay for this. The typical value was $8 \%$ of the purchase price of the books.

The British Library (BL) used a variation of contingent valuation, as being one of the few such methods accepted by the UK finance ministry, to assess the value of its national library services; both the direct benefits to users and the indirect benefits to the nation. This involved a variety of user surveys, including questions on what the users would have done if the BL services were not available, and what the consequent costs would have been, and also what amount of money users would accept to be happy if the BL did not exist. The study results suggested that the BL generates a value to the nation about 4 times its costs (British Library, 2004).

Aabo (2005) investigated the perceived value of the Norwegian public library service in a similar manner, presenting library users with a scenario in which the municipality was considering closing a library, and asking what they would be willing to pay to keep the library open, or alternatively what they would be willing to accept as compensation for its closure. By combining the results, it could be shown that the amount users would be willing to pay is roughly equivalent to current library costs per head of population, while the cost-benefit ration was about 1:4 (intriguingly, very similar to that found by the BL).

Despite some shortcomings and oversimplifications, contingent valuation methods seem the most acceptable means at present of evaluating cost-benefit of library services. It is likely that they will be further developed and used in the future, particularly as they have been applied to other services in the heritage sector such as museums

Assessment of impact would allow a determination of what 'real difference' a library or information service is making to its users, usually in terms of effects on their work. This approach has been most applied in workplace libraries, and within this sector most notably in healthcare libraries. Here, there has been a particular interest in attempting to show the impact of services, on factors such as improved patient outcome (increased survival, quicker recovery time, shorter stays in hospital), more reliable diagnosis, identification of best treatments, saving of time of medical staff, etc.) Numerous studies have examined this issue: see, for example, Robinson and Bawden (2007a, 2007b), Marshall (2007), Bryant and Gray (2006), and Weightman and Williamson (2005). It has proved difficult to show a conclusive relation between library/information provision and these desirable outcomes. However, there is an increasing body of evidence that information provided by a library / information service can influence patient care outcomes and that assessment of impact at a local level is possible by careful choice of evaluation methods. Impact studies are therefore likely to be increasingly adopted in the future, and in environments other than healthcare. An impact study of the public library service in Lithuania has recently been described 
(Rutkauskiene, 2008), and Poll and Payne (2006) discuss some projects that discuss how to determine the impact of higher education libraries on students' learning (the LIRG/SCONUL impact initiative, that developed into the VAMP project).

Assessment of the nature of the benefit provided goes beyond the 'simple' demonstration of value added, with the aim of providing an understanding of the detail of how and why the services provide value. One well-known example is the 'Value Project' (Urquhart and Hepworth 1995), a study that explored an approach to assessing the effectiveness of UK healthcare libraries as information providers and their effect on clinical decision-making and patient care. The study resulted in the development of a toolkit aimed at health sector information professionals to enable them to demonstrate the contribution their services were making. Like later work that emphasises the importance of learning from impact studies (Markless and Streatfield, 2006), the Value Toolkit aimed to enhance the impact of health library services. The evidence from impact should improve strategic planning, by providing a better understanding of customer behaviour, customer priorities and values. Although devised for the medical library environment, this toolkit has been adapted for use in other kinds of library (and updated guidance for health libraries has been published, Weightman, Urquhart, et al. 2008)

Impacts on individual information users are influenced by the policies in practice in the workplace. For healthcare, the prevailing ethos is that of evidence-based practice - decision making that is informed by the best evidence available. For libraries that are not bound to one particular type of organisation or workplace, the policy frameworks are different. Public libraries in England, for example, are represented at national government level by the Museums, Libraries and Archives Council (MLA), a non Non-Departmental Public Body (NDPB), sponsored by the Department for Culture, Media and Sport (DCMS). MLA produced an Inspiring Learning for All Toolkit (revised in 2009) to help museums, libraries and archives to assess their strengths and plan improvements, provide evidence of the impact of activities through generic learning and generic social outcomes, and improve their strategic and operational performance. The value of the learning outcomes from use of libraries is mapped to a variety of government policies concerning learning. The assumption, therefore, is that public libraries should be supporting informal and formal learning, and public libraries should be demonstrating their value in terms dictated largely by government policies. It might be expected that policies should reflect consumer needs, but not all members of the public may agree with the government on what is good for them.

Customer value is a very complex concept. The Value project (Urquhart and Hepworth, 1995) tried to identify the impact of the information provided by the library service, as a more objective measure than the associated perceived value of the library service, or its different activities. A systematic review of the research on perceived value, in marketing terms (Sánchez-Fernández and Iniesta-Bonillo, 2007) found considerable ambiguity in the literature on definition, dimensions and measurement of perceived value. For our purposes, in thinking about the value of information and library services, we need to remember that value is concerned with ideas around fitness for purpose (functional value,) social value (is this usage of information or library service expected of me), emotional value, desire for 
knowledge (which may overcome other irritations about the service) and the context (which is also dynamic - value judgements are not stable). Value is personal and relative - it can be enhanced according to proponents of customer relationship management (Broady-Preston and Felice, 2006). Customer value discovery research seeks to find out not only the major aspects valued but also the major irritants (McKnight, 2007).

If we are trying to find out how public library services are valued by their users, then perhaps the first step is to assess the impact of their services on the users, in particular how information obtained contributed to their learning, work and leisure.

\section{City of London study}

This study was carried out as the basis for a Masters degree in Library and Information Science at City University London, and fuller details of background, methods and results are given in the resulting dissertation (Calvert, 2007).

\subsection{Purpose and scope}

The purpose of this study was to evaluate whether the data collection tools and methods employed in the Value Project could be adapted and made relevant to the supply, use, outcomes and impacts of information in the public library context, to evaluate the extent to which the adapted tools and method could collect evidence of outcomes and impacts in this setting, and to discover the kinds of outcomes and impacts that these tools and methods can assess in a particular public library service, one that is more geared to the business sector and workplace needs than other services.

The Value Project looked specifically at the role of a library as information provider. For consistency, this project focused solely on specific information requests made in a public library as a result of some information need that is either made explicit or implied by the library user. The following scenarios were identified as candidates for the study on that basis:

- Requests for item reservations

- Inter-library loan requests

- Enquiry desk requests

- Reference desk enquiries

This means, of course, that non-users of the library, and users obtaining information through browsing, were not included.

\subsection{Survey methods}

The methodology of the Value Project was followed so far as was practical, with the main data collection by questionnaire and telephone interview survey of users. However the use of public libraries is diverse and is less predictable that the relatively homogenous use of health libraries. Therefore questions regarding the purposes for requesting information and what the information changed or enabled needed to be adapted. 
A framework of 'impact themes' was derived, based on an analysis of relevant 'information impact' studies from the literature. These themes were used to generate questionnaire and interview questions of relevance to the public library setting.

The purpose of the information request was assigned to a set of seven categories appropriate to the public library context:

- recreational

- educational

- career-related

- $\quad$ professional and business

- personal

- community-related

- health-related

with a catch-all 'other' category also available.

Within each, the benefits of information obtained were investigated, including both immediate impact, and longer-term effects.

A first category of questions dealt with immediate impact: quality of provision, how information fits into the existing knowledge base of users, and factors relating to the utility and usefulness of information provided. A second category, dealing with how information will or might contribute in the future, was expanded from the original formulation of the Value Project to encompass what outcomes the information enabled, the degree of change, and changes at an emotional or personal level. This was intended to provide a flexible design in which the purpose could provide some context for the factors of outcome and impact that in combination were designed to provide an indication of the subjective value-inuse.

In keeping with the original survey closed questions were used with 'yes', 'no' and 'not applicable' responses available that collected nominal data in categories of user type, purpose and impact surrogates. However an ordinal rating scale was used to capture the degree of change experienced by users as they perceived it against a series of aspects.

An open-ended question included in a pilot survey asked for views on the questionnaire itself. The issues noted were that of redundancy, the amount of paper used and the size of the envelopes provided. Interpretation did not appear to be a problem although this does not guarantee it was exactly as intended.

The design of the interview largely followed that of the questionnaire. The purpose was to provide more detail on exactly how the information led to the impacts and outcomes reported in the questionnaire. In addition some context and background regarding the purpose and use of information was collected.

Urquhart and Hepworth (1995) used data held by hospital administration, such as staff lists for the purposes of their study. For this study, the use of similar data, 
such as member lists and loan histories to contact users who had made specific information requests was infeasible for reasons of data protection. Therefore a question regarding member type (or equivalent demographic category for reference libraries) was added to the questionnaire.

The final version of the questionnaire is shown in Appendix 1.

The preferred distribution method for use in the lending libraries also had to be redesigned, which made achieving a random sample more difficult. The questionnaires were distributed 'anonymously' when requested items were collected or at the reference libraries, when enquiries were made. Wherever possible every user making a request in the reference libraries was asked to take part. To keep the questionnaires anonymous, participation in the interview was voluntary. A separate 'opt-in' contact form was included for those wishing to take part to keep the questionnaires themselves anonymous. Those who volunteered to take part were contacted by telephone after some weeks. This was chosen to allow time between completing the questionnaire and the interview for further impacts to be felt. Each interview was conducted over the telephone at a time chosen by participants and recorded with their consent. After the completion of each interview the contact sheets were securely destroyed and each recording was transcribed.

A small pilot study was conducted in March 2007 at all sites, with the main phase of the study conducted from the end of April 2007 to the beginning of June 2007.

The data gathered using the research instruments was either:

- Nominal quantitative data - categories of user type, purpose of use and categories of effect/impact/outcome

- Ordinal quantitative data - scaled response against a set of categories of possible impacts.

- Qualitative data - text produced from interview transcriptions.

Because of the nature of the data, the relatively small size of the data set, and the non-random nature of the sample, analysis of the survey data was limited to descriptive statistics using tables and graphical representation, and qualitative assessments of response patterns, proportions and themes based on the devised framework. Analysis of the interview data was conducted using the framework, with classes of impact and sub-themes given codes. The interview transcriptions were annotated with these codes after which tables were constructed containing transcription extracts.

\subsection{Results}

In total 242 surveys were distributed of which 109 were returned, giving a return rate of $45 \%$. The split between libraries is shown in Table 1. The City Business Library, a specialist reference library within the City of London public library service, was unable to take part in the main survey, for operational reasons. 


\begin{tabular}{|c|c|c|c|}
\hline \multicolumn{4}{|c|}{ Survey distribution by library } \\
\hline Site & Distributed & Returned & $\%$ Returned \\
\hline Barbican Library (lending) & 90 & 34 & $38 \%$ \\
\hline Camomile Street Library (lending) & 50 & 20 & $40 \%$ \\
\hline Shoe Lane Library (lending) & 40 & 19 & $48 \%$ \\
\hline City Business Library (reference) & 12 & 6 & $50 \%$ \\
\hline Guildhall Library (reference) & 50 & 30 & $60 \%$ \\
\hline \hline TOTAL (Lending) & 180 & 73 & $58 \%$ \\
\hline TOTAL (Reference) & 62 & 36 & \\
\hline
\end{tabular}

\section{Table 1: Survey distribution by library site and type}

Types of Lending Library user were determined by the users' library membership type. Greater detail was collected to account for reference library users to make data sets for each type of library compatible. This was dependent on whether they lived, worked or studied in the City or elsewhere leading to a slightly different set of categories than those usually used for library membership, as shown in Table 2.

\begin{tabular}{|l|c|}
\hline $\begin{array}{l}\text { LIBRARY MEMBERSHIP } \\
\text { CATEGORIES }\end{array}$ & RETURNS \\
\hline City Worker & 52 \\
\hline City Student & 1 \\
\hline City Resident & 7 \\
\hline Non-City & 44 \\
\hline Other Student & 5 \\
\hline
\end{tabular}

\begin{tabular}{|l|c|}
\hline $\begin{array}{l}\text { USER TYPES (NON- } \\
\text { LIBRARY CATEGORIES }\end{array}$ & RETURNS \\
\hline City Worker & 52 \\
\hline City Resident & 7 \\
\hline Non-City Worker & 15 \\
\hline Non-City Residents & 29 \\
\hline Student (All) & 6 \\
\hline
\end{tabular}

\section{Table 2: Total user types by both library membership and non-library categories}

The results, set out in full in Calvert (2007) are extensive and detailed, and cannot be reproduced in full here for reasons of space. A summary of the main findings only, with some exemplar detail, is given here.

Users' requests for information were categorized, as noted above, in six categories. [The original 'health' category drew only one response, and it was subsumed within 'personal'. The 'other' category was not needed.] Purposes were as follows (some users noting more than one purpose for a request:

$\begin{array}{llll}\text { recreational } & 55 & \text { educational } & 46 \\ \text { professional } & 21 & \text { personal / health } & 18 \\ \text { career-related } & 12 & \text { community-related } & 6\end{array}$


The analysis of users' answers to questions, set within the analysis framework, addressed issues of whether the information obtained was appropriate, to what extent it met the need, and how it fitted the current knowledge of the users, what they would now do with the information, how, and to what extent, it would change their situation, and what might be the 'emotional' effects (confidence, motivation, inspiration, insight into something new etc.).

\begin{tabular}{|l|c|c|c|}
\cline { 2 - 4 } \multicolumn{1}{c|}{} & $\begin{array}{c}\text { TOTAL }- \\
\text { Yes }\end{array}$ & $\begin{array}{c}\text { TOTAL }- \\
\text { No }\end{array}$ & $\begin{array}{c}\text { TOTAL - } \\
\text { N/A }\end{array}$ \\
\hline Met expectations & 97 & 7 & 4 \\
\hline Suitable for purpose & 96 & 4 & 8 \\
\hline Refreshed knowledge/skills & 79 & 2 & 27 \\
\hline Partially or completely new & 53 & 13 & 43 \\
\hline Substantiated what was known & 53 & 32 & 24 \\
\hline Could use at least part immediately & 50 & 10 & 48 \\
\hline Need more information/another item & 66 & 5 & 38 \\
\hline Did not provide me with want I needed & 41 & 27 & 41 \\
\hline Was mostly irrelevant & 11 & 67 & 30 \\
\hline Came too late to be useful & 13 & 65 & 30 \\
\hline
\end{tabular}

Table 3: Immediate effects of information requested 


\begin{tabular}{|l|c|c|c|}
\cline { 2 - 4 } \multicolumn{1}{c|}{} & $\begin{array}{c}\text { TOTAL - } \\
\text { Yes }\end{array}$ & $\begin{array}{c}\text { TOTAL - } \\
\text { No }\end{array}$ & $\begin{array}{c}\text { TOTAL - } \\
\text { N/A }\end{array}$ \\
\hline Mearn something new & 73 & 15 & 19 \\
\hline Make progress in a task or project & 65 & 11 & 33 \\
\hline Solve a problem & 33 & 30 & 44 \\
\hline Enjoy my leisure/spare time & 64 & 18 & 26 \\
\hline Take some action & 26 & 28 & 53 \\
\hline Make new contacts & 18 & 31 & 56 \\
\hline Participate in something & 26 & 25 & 57 \\
\hline Open/exploit new opportunity & 22 & 30 & 55 \\
\hline Handle an emergency & 3 & 34 & 70 \\
\hline Cope with/adapt to change & 9 & 33 & 65 \\
\hline Minimise some risk & 6 & 31 & 70 \\
\hline Take on new responsibilities & 10 & 31 & 66 \\
\hline Provided access to something & 23 & 20 & 61 \\
\hline Find help/support & 11 & 31 & 65 \\
\hline Do business/operate a business & 11 & 31 & 65 \\
\hline Avoid conflict & 3 & 28 & 72 \\
\hline
\end{tabular}

\section{Table 4: What the information enabled users to do}

The following data tables and associated quotations give a 'flavour' of the kind of rich and detailed results obtained from the analysis of the questionnaire and interview results. Figure 1 exemplifies the assessment of the extent of change brought about by information for the recreation category. Figure 2 shows the analysis of the outcomes of obtaining information in the community category.

"..the writer deals with things about about the international movement of people and activities. I think it's a bit futuristic in some of its sociological outlooks, but I'm not sure that there's actually much I can apply out of it other than to be a more rounded and knowledgeable person ... I think there's a touch of confirmation of one's own values but also helps put one's own situation in context".

"We were able to confirm what we knew and it gave us a lead to other possible sources .. our plans are to assemble what we can, as much material as we can and then distil it into an interesting and accessible narrative ... it did help us fairly significantly to go forward with the project, I can't put that in percentage terms at all, but it was very helpful in that sense" [local historian]. 


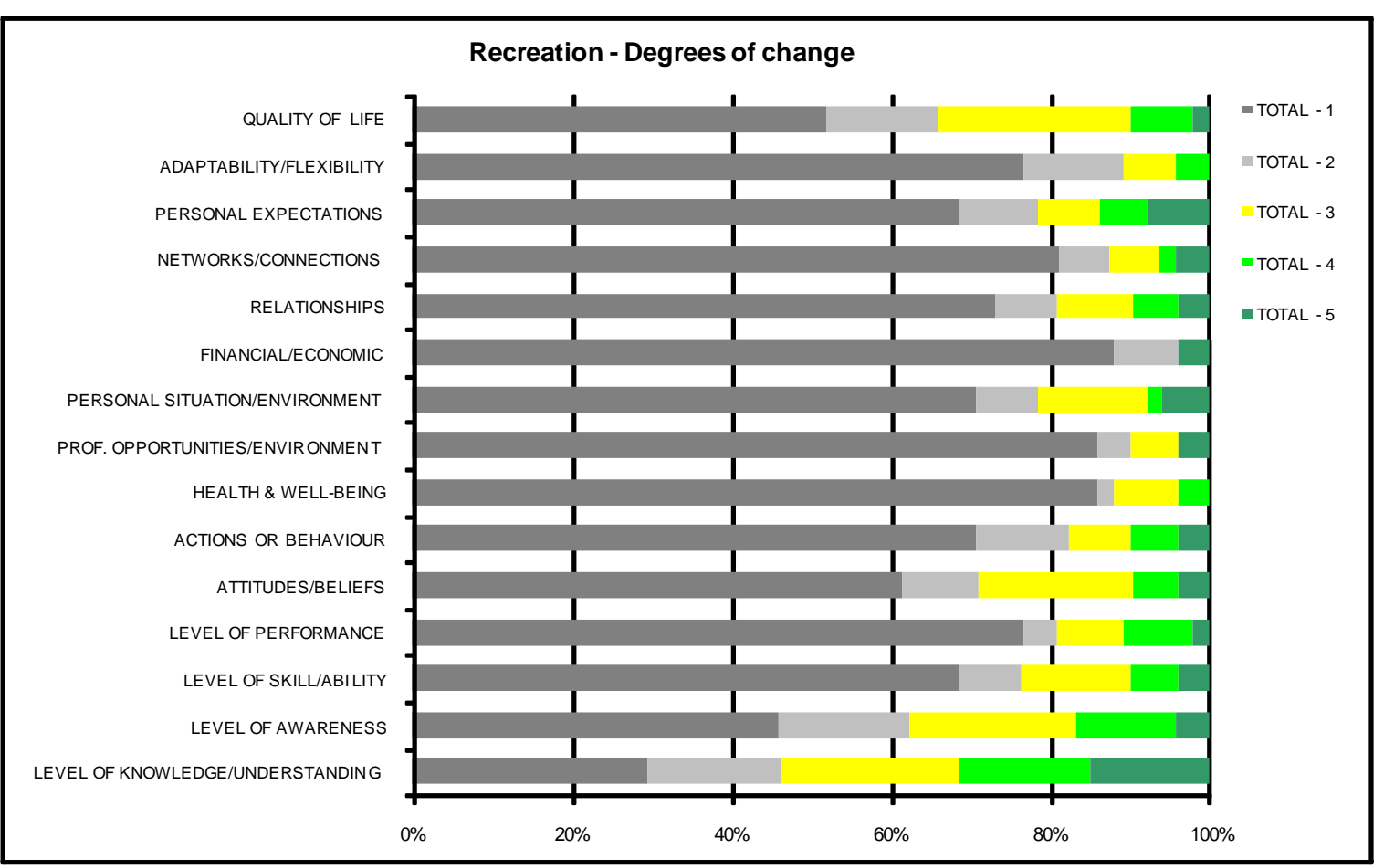

Figure 1: Degrees of change rated 1 to 5 for recreation category

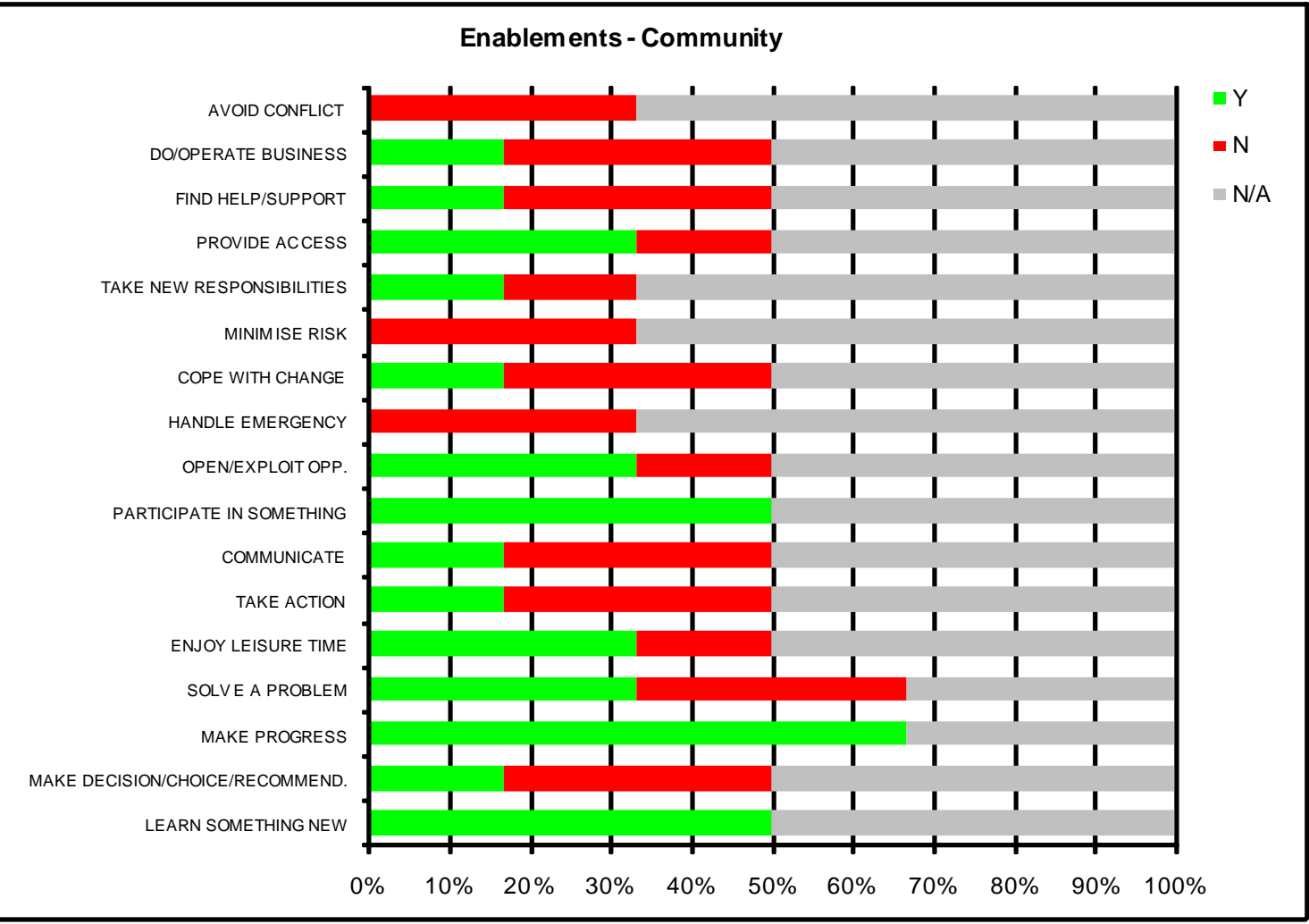

Figure 2: Outcomes for community category 


\subsection{Conclusions for City of London}

The results of this study, admittedly small scale, demonstrated that the libraries involved have made a positive impact for the users that took part, and provided quantitative evidence that demonstrates where the libraries are making an impact.

Particular themes were:

- Learning - the study found strong positive impacts on learning in a wide variety of contexts and across all categories of use. It has been demonstrated that the libraries enable the users involved in this study to learn in both intended and indirect ways and that users recognise this impact.

- Supporting leisure - recreation was the most common reason for using the libraries and therefore this might seem inevitable, however many use selfdirected educational activities as leisure pursuits both during their working lives and beyond. Through this, the study found that they get stimulation and to a lesser degree maintain their health, a factor that was more evident in the interviews. The libraries are playing an important role for users in supporting these activities in ways that encourage and motivate individuals to further their interests, leading to involvement in other things.

- Supporting business and professional activity - although this purpose accounted for only about $20 \%$ of instances captured in the study, the results in this category showed some of the most dramatic results, particularly amongst the degrees of change. These impacts were not just as a result of learning to support professional activity but also in the practical application of the information used, such as taking action and decision-making. [As noted above, the City Business Library could not take part in the main study; had it done so, this aspect would certainly have shown more importance.]

- Personal life and development - whilst the study did not capture a large number of instances they showed strong positive results indicating that the libraries were playing an important role in supporting personal development through providing information. In addition the responses for this group showed high levels of information-based activity that was in common with professional and business use.

These results show that the approach, adapted from a toolkit for analysis of healthcare library effectiveness, has potential for conducting self-assessment analyses in public libraries. In addition, isolating specific instances of use appears to have addressed the difficulty in separating the impact of libraries from other contributing factors to some degree.

The approach was, however, found to have several limitations. Broader and longer-term impact was not fully captured. Quality of life factors also proved problematic and whilst indirect indicators were more useful, the lack of interview data in some areas limited how these could be used. Access and use of library user data affected the distribution of questionnaires, which importantly meant a random sample was not possible. This issue might need to be addressed in future similar studies. 


\section{South West England study}

This study was carried out in six public library authorities in South West England (Bath and North East Somerset, Devon, Plymouth, Somerset, South Gloucestershire, and Wiltshire) in 2006. Fuller details are given in the project report (Devon County Council, 2006); see also Amosford (2007), Bray (2007).

\subsection{Purpose and scope}

This study was designed to investigate 'generic learning outcomes' obtained by library users who had borrowed books from public libraries in the South West of England. It built on a smaller scale survey, and de facto pilot study, carried out in Exeter Central Library, in the previous year. The questions were based on the Museums, Libraries and Archives Council's set of generic learning outcomes (which were based on a model developed for museums, Hooper-Greenhill, 2000):

- knowledge and understanding

- activity behaviour and progression

- enjoyment, inspiration and creativity

- $\quad$ attitudes and values

- $\quad$ skills

Both fiction and non-fiction was included in the analysis. The emphasis here was on book borrowing but the kind of requests for information considered in the City of London study were not included.

\subsection{Survey methods}

The study relied on questionnaires completed by library users, which were placed in books as they were lent; completed questionnaires were either returned with the book, or placed in a collection box at another time. The survey asked some other questions about satisfaction with the book and the collection in general.

The purpose of borrowing the book was identified from the categories:

- $\quad$ private study

- formal study

- $\quad$ sharing with or teaching others

- personal enjoyment

- other

Benefits were assessed against the learning outcomes for that user by asking whether the book had:

- motivated or inspired [entertainment, inspiration, creativity]

- $\quad$ provided insight [knowledge and understanding]

- $\quad$ helped develop skills [skills] 
- changed daily life

- changed opinions

- brought personal benefit

- $\quad$ helped learn new facts

- challenged attitudes

- entertained [attitude, behaviour, progression]

[attitudes and values]

[activity, behaviour, progression]

[knowledge and understanding]

[attitudes and values]

[entertainment, inspiration, creativity]

The users were then prompted to make free comments, amplifying or explaining any aspects.

\subsection{Results}

A total of 5379 questionnaires were received, response rates varying between $17 \%$ and $24 \%$ for the various libraries. Sixty eight per cent of the responses related to fiction material, $32 \%$ to non-fiction.

The full results are set out in the project report (Devon County Council 2006).

The purposes of borrowing the book were as follows (Table 5) (percentages):

\begin{tabular}{|l|l|l|}
\hline & Fiction & Non-fiction \\
\hline Private study & 1 & 27 \\
\hline Formal study & 0 & 3 \\
\hline Sharing with or teaching others & 1 & 2 \\
\hline Personal enjoyment & 97 & 58 \\
\hline Other & 1 & 11 \\
\hline
\end{tabular}

Table 5: Purposes of book borrowing

The outcomes (Table 6), expressed as the percentage who agreed or strongly agreed that the book had provided each of them, were as follows: 


\begin{tabular}{|c|c|}
\hline Knowledge and understanding: & \\
\hline Insight & 50 \\
\hline Facts & 50 \\
\hline Skills & 15 \\
\hline Attitudes and values: & \\
\hline Challenge attitudes & 17 \\
\hline Change opinions & 13 \\
\hline Entertainment, inspiration, creativity: & \\
\hline Entertain & 81 \\
\hline Motivate or inspire & 29 \\
\hline Activity, behaviour and progression: & \\
\hline Change daily life & 27 \\
\hline Personal benefit & \\
\hline
\end{tabular}

\section{Table 6: Learning outcomes from book borrowing}

Increase in knowledge and understanding, and entertainment, were clearly the most highly accepted benefits. Relatively few indicated that they had gained new skills, and fewer still that daily life had changed; these being the sort of 'direct impacts' sought by the strict form of 'impact study'. (Though the fact that one in twenty readers suggest that their daily life had changed as a result of borrowing a library book might give some 'life coaches' pause for thought.)

Over $70 \%$ of readers claimed to have wholly or mostly got what they wanted from the book. Over $90 \%$ claimed it was easy to find. $90 \%$ felt that the fiction stock of interest to them was good, 74 felt so for non-fiction.

The report provides a more detailed breakdown into the responses for fiction and non-fiction, and supplements this by quotations, indicative of the insight into the nature of benefits:

"I found two of the short stories insightful, and they made me aware of different aspects of well known events"

"science fiction is entertainment, but some books will help change or form new concepts"

"Learn other techniques, consolidate and affirm what I already know" 
"To help me change my fast life ... to slow down".

To further refine understanding of benefits, a random sample (10\%) of the comments for fiction was examined, using Bloom's taxonomy of learning objectives in the affective domain (Bloom, 1956). The aim was to assess whether it might be possible to devise a more detailed set of learning outcomes that would better represent the range of learning outcomes indicated in the comments, and fully represent the learning associated with fiction books.

Bloom's taxonomy of affective learning outcomes should apply to the learning associated with emotional understanding of a situation or people. The outcome 'entertain you' seems insufficient to encompass all the types of engagement that may be taking place with fiction books, and fiction services. Many of the comments on the books indicated that readers were relating to the books they had read, indicating that they were critically reviewing the content and appraising them not just for themselves but for other readers as well. Other comments indicated that the books had 'affected' the readers in some way, and that they had understood a particular setting better. It may be useful to discriminate the types of affective learning outcome that may be associated with the entertainment gained from reading a book, particularly a fiction book.

Bloom's taxonomy of learning objectives in the affective domain covers appreciation, enthusiasm, motivations and attitudes. There are five major categories, going from the simplest (receiving) to the most complex (characterisation). These objectives were aimed at classroom learning at the time they were developed, and it may not be easy to transfer these ideas to individual reading, and open-ended comments made on a questionnaire to be completed by informal learners. However, Bloom's taxonomy for the cognitive domain has been used in a variety of learning situations, and the taxonomy for the affective domain seems a good starting point for assessing any difference made to the views or understanding of fiction books borrowed from the public library.

Many of the comments are not detailed enough to sort them into definitive categories although all, almost by definition, show some evidence of 'receiving' or 'responding' as the respondents have participated in the questionnaire survey and many have made suggestions. The following illustrates examples drawn from the comments on the questionnaire of categories in the taxonomy.

\section{'Receiving'}

(Receiving phenomena Awareness, willingness to hear, selected attention)

"I found the story very moving and the insight into the reactions of the various characters absolutely believable."

"I found this book very amusing. I think the conception of retirement homes abroad is very interesting."

"This fiction book provided interesting and informative background about the lifestyle of the people and the climate conditions in Alaska." 


\section{'Responding'}

(Responding to phenomena Active participation, making suggestions,(when requested, or voluntary)

"Possibly the most inspiring and thought-provoking book in the library or at any rate in the 500s sections. More of Ervin Laszle's books please."

"Update books on issues which are continually developing, e.g. cancer."

\section{'Valuing'}

(Accepting the worth of a thing, assuming some responsibility (commitment))

“A few more latest best sellers wouldn't go amiss. Being so near Cornwall - very poor selection about speaking and writing Cornish even though it's of little use nowadays."

"Try to find more books from Russian writers of the great patriotic war so as to at least try to give a more balanced approach from which we can form an opinion."

\section{'Organising'}

(Organises values into priorities, recognising interrelationships, adapting behaviour to value system)

\section{'Characterising'}

(Having a value system that controls behaviour, showing internal consistency)

No comments on organisation and characterisation were found. Out of the selection no comments seemed to fit into the higher level categories of organisation or characterisation, but this type of outcome would probably have to emerge from interviews or focus group work with readers.

\subsection{Conclusions for South West England}

The results of this study showed that user views were on the whole positive and similar proportions for fiction and non-fiction received. In general almost all responses suggested that the reader got at least some form of learning outcome from the book borrowed, and the majority got what they wanted from the book. Where a learning outcome was not identified this was often due to a failing in the book not meeting the need of the reader.

This project, as with the City of London study, indicated the value of this general approach in establishing the nature of the impact of library services. Again, the use of a detailed framework for analysis, although problematic in some respects, enabled rich information to be identified.

\section{Discussion}

The discussion examines the feasibility of adapting an impact framework from the other sectors for use in public libraries, and the implications for assessing the value of public library services

For the City of London study, the impact framework adapted the principles of the Value project framework (itself evidence-based) by synthesising other impact 
research to derive a framework of types of change. The impact framework was evidence-based, and this covered the categorisation of likely purposes as well as the idea of enablement and degree of change.

For the SW England study, the MLA Generic Learning Outcomes were influenced largely by research on learning and museums, and the website now offers different advice (from that available when the study was done). One of the startling, but not unexpected findings in the SW England evaluation was the high proportion of responses that indicated the main purpose of reading fiction was personal enjoyment (and this was reflected in the City of London study). The book borrowers indicated that entertainment was the main outcome, with motivation and inspiration a lesser outcome. For libraries wishing to show the contribution to 'learning', this may not seem good news, but other research indicates that reading fiction does help us to be more aware of social situations and how to 'play them' - reading may perform the same function for our social skills as motor racing computer simulation games do for drivers in improving their driving skills (Oatley, 2008).

For the SW study the use of Bloom's taxonomy for affective learning outcomes was successful in starting to tease out some of the affective learning outcomes that Oatley (2008) notes as an effect of reading fiction. For the City of London study, the outcomes categorised under Recreation that were associated with the most change cannot be compared directly with the SW England study, as the latter was examining book borrowing, not necessarily as purposive as those activities examined in the City of London study. However, taking the main affective outcomes, in terms of degree of change (Figure 1) for the City of London study, there are possible relationships between these and the categories described by Bloom's taxonomy (Figure 3). Interestingly, the SW sample failed to find evidence of organising and characterising outcomes, but these seem to be evident in the City of London library study. Perhaps these require the library users to be prepared, or purposive. This comparison omits the main degree of change category, level of knowledge/understanding, and also level of skill/ability, but these are not interpreted as affective outcomes. Taking the major degrees of change (rated 3 or above) the prominent categories in the City of London study were personal expectations, and awareness (which may relate directly to Bloom's taxonomy), attitudes/belief, relationships and personal expectations (the latter three could relate to valuing in the Bloom taxonomy, but that would require validation in interviews to check whether the degree of response implied in the Bloom taxonomy was met.

One difficulty with impact studies is the problem of separating satisfaction with the setting (library and staff) from the effect of the information provided by the response to the enquiry or the borrowed item. Library services often wish to determine a value that encompasses the physical setting, the attitudes and helpfulness of the staff, as well as the value of the information provided. There probably is a halo effect - higher impacts may be attributed if library users are very satisfied with the service. The SERVQUAL framework for service quality assessment is itself affected by the particular life experiences of library users ( $\mathrm{Yu}$ et al. 2008) suggesting that even a simple satisfaction rating can be suspect. Impact frameworks need to be specific, and relevant to the user. The more 
specific the framework the more likely it is that the library user will focus on the information provided than perceptions of the provider, and a relevant framework will help. The similarities and differences in the types of impacts identified in the two studies suggest that the impact framework should be tailored to the type of item or request being assessed as well as the likely range of outcomes. The MLA framework was based on one used for museums, where educational visits are common. The SW England library findings indicated that the affective learning outcomes are far more relevant to fiction book borrowing, and the City of London study found that recreation was the main purpose, although education was a close second.

\section{Conclusions}

The aim of this paper was to compare two impact studies in public libraries, to examine the frameworks used for impact assessment and the compare, as far as possible, the findings.

Adaptation of existing frameworks is possible and effective, but the framework needs to be based on evidence from research on user behaviour and expectations in the sector of study. Simply expecting that libraries should demonstrate learning impacts as policymakers expect may mean that more subtle impacts may be missed. When devising the framework it is important to consider the setting and the type of population served, and the type of library activities and outputs to be assessed. These will affect the degree of emphasis to be placed on some types of impact.

\section{References}

Aabo, S. (2005) Are public libraries worth their price?, New Library World, 106(11/12), 487-495.

Amosford, J. (2007) Assessing generic learning outcomes in public libraries. Performance Management and Metrics, 8(2), 127-136.

Bawden, D., Petuchovaite, R., and Vilar, P. (2005) Are we effective ? How would we know? Approaches to the evaluation of library services in Lithuania, Slovenia and the United Kingdom, New Library World, 106(1216/1217), 454-463.

Bloom, B.S. (Ed.) (1956) Taxonomy of educational objectives, the classification of educational goals, by a committee of college and university examiners, Handbook 2: the affective domain. London: Longman.

Booth, A. (2004) Evaluating your performance. In A. Booth and A. Brice (Eds.), Evidence-based practice for information professionals, pp.124-137. London:

Facet Publishing.

British Library (2004) Measuring our value. URL: http://www.bl.uk/aboutus/stratpolprog/increasingvalue/measuring.pdf [accessed 27.07.09].

Bray, C. (2007) Libraries inspire learning, Public Library Journal, 22(2), 15-16. 
Broady-Preston, J., and Felice, J. (2006) Customers, relationships and libraries: University of Malta, a case study. Aslib Proceedings, 58(6), 525-536.

Bryant, S.L., and Gray, A. (2006) Demonstrating the positive impact of information support on patient care in primary care: a rapid literature review. Health Information and Libraries Journal, 23(2), 118-125

Calvert, A. (2007) "If I had a hammer ..." : Adapting and testing a health sector tool to assess outcomes and impacts in a public library, unpublished Masters dissertation, Department of Information Science, City University London.

Chung, H.K. (2008) The contingent valuation method in public libraries. Journal of Librarianship and Information Science, 40(2), 71-80

Crawford, J. (2006) The culture of evaluation in library and information services, Oxford: Chandos Publishing.

Creaser, C., Conyers, A., and Lockyer, S. (2007) VAMP - laying the foundations. Performance Management and Metrics, 8(3), 157-169.

Devon County Council (2006) Reading a Difference. URL:

http://www.devon.gov.uk/index/culturetourism/libraries/librarypoliciesplanningre port [accessed 25.7.09].

Hooper-Greenhill, E. (2000) Museums and the interpretation of visual culture. London: Routledge.

Imholz, S., and Arns. J. W. (2008) Worth their weight: an assessment of the evolving field of library evaluation. Public Library Quarterly, 26(3-4), 31-48.

Marshall, J.G. (2007) Measuring the value and impact of health library and information services: past reflections, future possibilities. Health Information and Libraries Journal, 24(1), 4-17.

Matthews, J.R. (2007) The evaluation and measurement of library services, Westport CT: Libraries Unlimited.

McKnight, S. (2007) Acquisition and cataloguing processes: changes as a result of customer value discovery research. Evidence Based Library and Information Practice, 2(4), 22-36. URL:

http://ejournals.library.ualberta.ca/index.php/EBLIP/article/view/521/667 [accessed 14 12.09].

Morris, A., Sumsion, J., and Hawkins, M. (2002) Economic value of public libraries in the UK. Libri, 52(2), 78-87

Museums, Libraries and Archives Council (MLA) (2009) Inspiring learning: an improvement framework for museums, libraries and archives. URL: http://www.inspiringlearningforall.gov.uk/ [accessed 13.07.09].

Oatley, K. (2008). The science of fiction. New Scientist, 198(2622, 28 June), 4243.

Poll, R., and Boekhorst, P.T. (2007) Measuring quality performance measurement in libraries ( $2^{\text {nd }}$ edn.), IFLA Publications vol.127, Munich: K.G. Saur. 
Poll, R., and Payne, P. (2006) Impact measures for libraries and information services. Library Hi-Tech, 24(5), 547-562.

Robinson, L., and Bawden, D. (2007a) Measuring the impact of healthcare information services. Informacijos Mosklai (Information Sciences, Vilnius University), 40, 95-103.

Robinson, L., and Bawden, D., (2007b) Evaluation of outreach services for primary care and mental health: assessing the impact. Health Information and Libraries Journal, 24(s1), 57-66.

Rutkauskiene, U. (2008) Libraries are good: prove it. Fifth Naple conference in Vilnius, 9-11 October. URL:

http://www.naple.info/Vilnius/ugne_rutkauskiene.pdf [accessed 25.1.10].

Sánchez-Fernández, R., and Iniesta-Bonillo, M. A. (2007) The concept of perceived value: a systematic review of the research. Marketing Theory, 7(4), 427-451.

Urquhart, C., and Hepworth, J.B. (1995) The value of information supplied to clinicians by health libraries: devising an outcomes-based assessment of the contribution of libraries to clinical decision making. Health Libraries Review, 12(3), 201-213.

Weightman, A., and Williamson, J. (2005) The value and impact of information provided through library services for patient care: a systematic review. Health Information and Libraries Journal, 22(1), 4-25.

Weightman, A., Urquhart, C., Spink, S., and Thomas, R. (2008) The value and impact of information provided through library services for patient care: developing guidance for best practice. Health Information and Libraries Journal, 26(1), 63-71.

Yates-Mercer, P.A., and Bawden, D. (2002) Managing the paradox: the valuation of knowledge and knowledge management, Journal of Information Science, 28(1), 19-29

Yu, L., Hong, Q., Gu, S., and Wang, Y. (2008) An epistemological critique of gap theory based library assessment: the case of SERVQUAL. Journal of Documentation, 64(4), 511-551.

\section{Acknowledgement}

The authors thank all those who supported the surveys discussed in the paper. 


\section{Appendix 1}

\section{City of London Questionnaire}

Thank you for taking part in this study.

Please complete the questionnaire once you have had a chance to read or use the item or information that was supplied by the library. If you received or requested multiple items they can all be used for completing the survey provided you requested them for the same purpose, otherwise please choose one.

Completed questionnaires should be returned in the stamped addressed envelope provided before $1^{\text {st }}$ June 2007. Thank you.

\begin{tabular}{|c|c|c|c|}
\hline Q.1a & $\begin{array}{l}\text { Please select one of the following that best represents your library } \\
\text { membership or your use of the library on this occasion: } \\
\text { (Please tick) }\end{array}$ & & \\
\hline \multirow{2}{*}{\multicolumn{2}{|c|}{$\begin{array}{l}\text { City worker } \ldots \ldots \ldots \ldots \ldots \ldots \ldots \ldots \ldots \ldots \ldots \ldots \ldots \ldots \\
\text { City resident (not working or studying in the City) please see } Q .1 b \ldots \ldots \ldots \ldots \ldots\end{array}$}} & & [2] \\
\hline & & $\square$ & [3] \\
\hline \multicolumn{4}{|c|}{ Non-City ... } \\
\hline \multicolumn{2}{|c|}{ 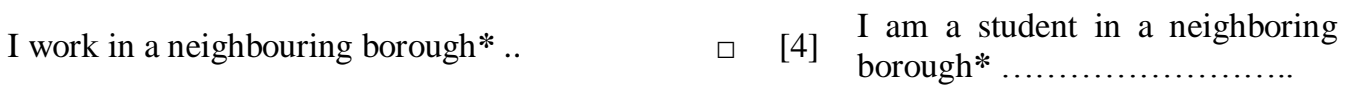 } & $\square$ & [5] \\
\hline \multicolumn{2}{|c|}{ I live in a neighbouring borough* (not working or a student) please see $Q .1 b \ldots$} & & [6] \\
\hline \multicolumn{2}{|c|}{ I work elsewhere $\ldots \ldots \ldots \ldots \ldots \ldots \ldots$} & $\square$ & [8] \\
\hline \multirow{2}{*}{\multicolumn{2}{|c|}{$\begin{array}{l}\text { I live elsewhere (not working or a student) please see } Q .1 b \ldots \ldots \ldots \ldots \ldots \ldots \ldots \ldots \\
\text { * London Boroughs of Islington, Hackney, Tower Hamlets, Camden, Southwark or Westminster. }\end{array}$}} & $\square$ & [9] \\
\hline & & & \\
\hline
\end{tabular}

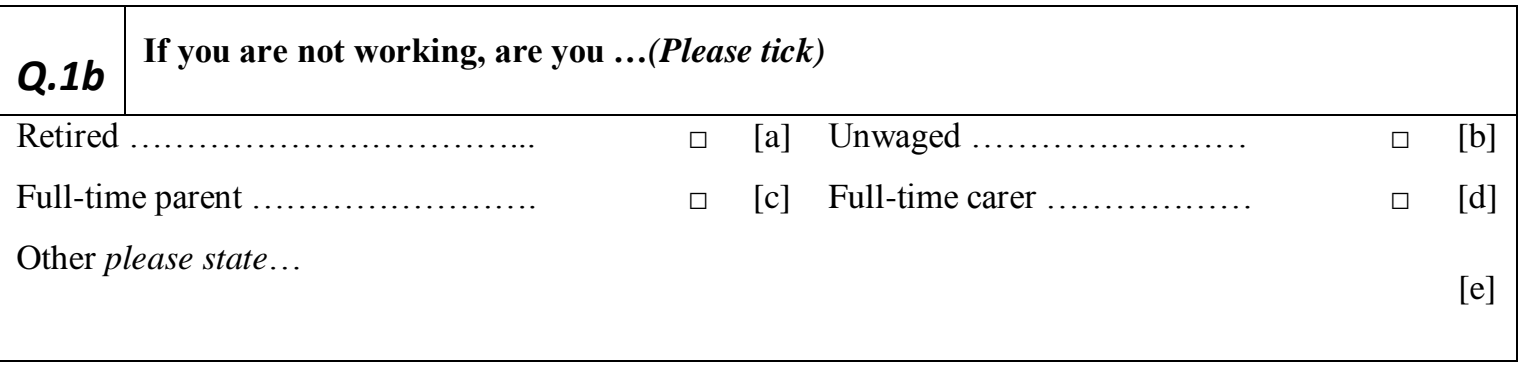




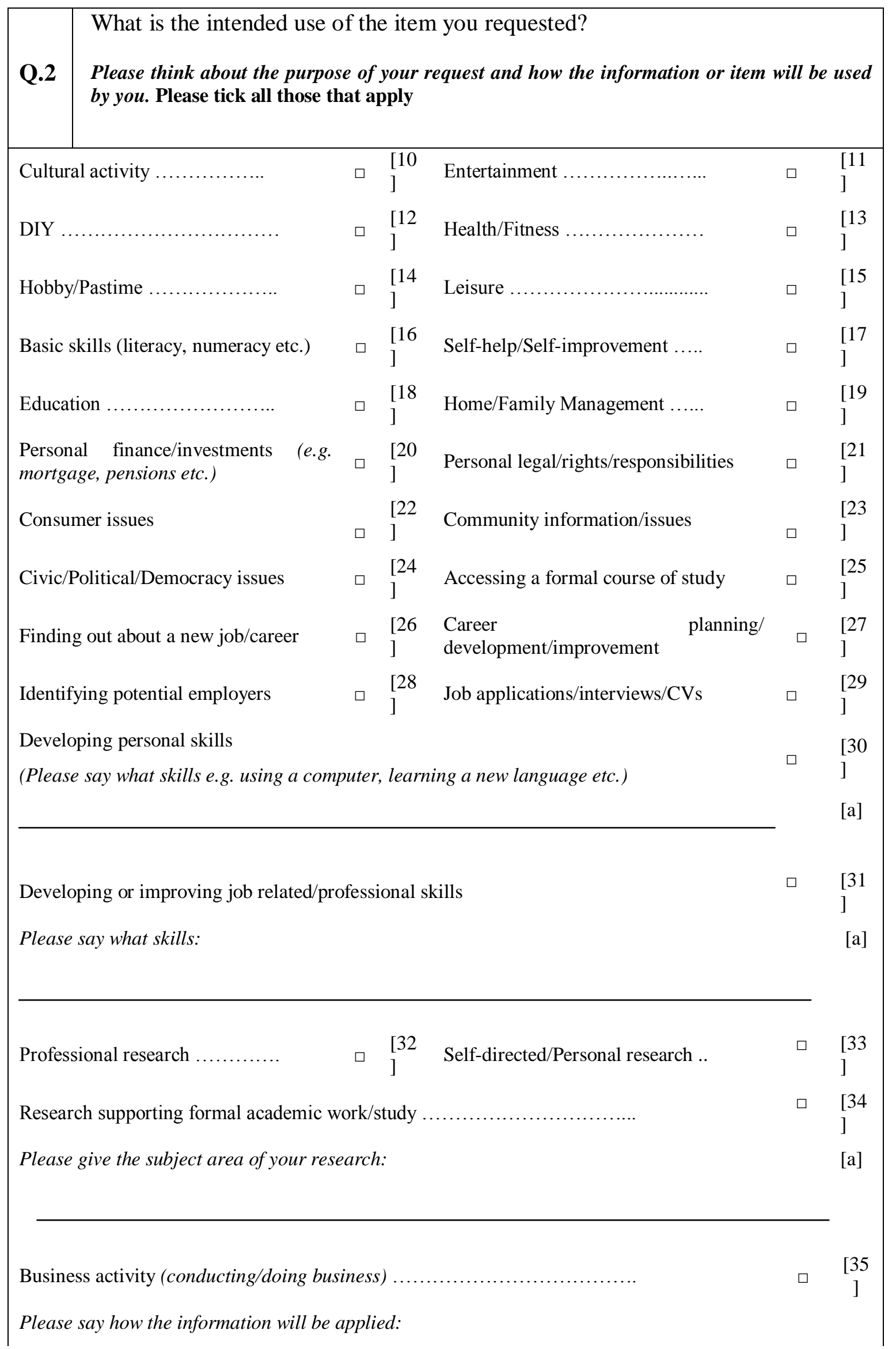


Starting a business

Marketing a business

Business law/responsibilities ....

Sourcing business services

Applying for grants/assistance

Other (please state):

In what size and type of business will this information be used? (please state):

Other use not listed (please state):

\begin{tabular}{|c|c|c|c|}
\hline Q.3 & $\begin{array}{l}\text { What prompted you to make a request on this occasion? } \\
\text { (Please tick appropriate categories) }\end{array}$ & & [37 \\
\hline \multicolumn{2}{|r|}{ Suggestion/information/advice from friend/colleague $\ldots \ldots \ldots \ldots \ldots \ldots \ldots \ldots$} & $\square$ & [a] \\
\hline \multicolumn{2}{|c|}{ Enquiry from someone else } & $\square$ & [b] \\
\hline \multicolumn{2}{|c|}{ Previous information or item } & $\square$ & {$[\mathrm{c}]$} \\
\hline \multicolumn{2}{|r|}{ 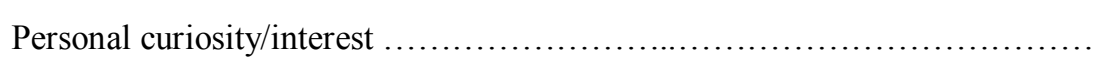 } & $\square$ & [d] \\
\hline \multicolumn{2}{|r|}{ Specific needs of a task/project/activity............................... } & $\square$ & [e] \\
\hline \multicolumn{2}{|r|}{ Reported on TV/radio or in a newspaper/magazine $\ldots \ldots \ldots \ldots \ldots \ldots \ldots \ldots$} & $\square$ & {$[\mathrm{f}]$} \\
\hline \multicolumn{2}{|r|}{ 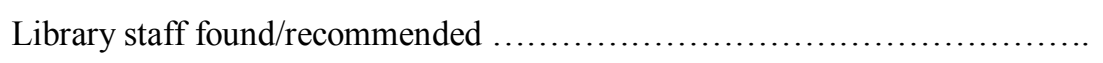 } & $\square$ & {$[\mathrm{g}]$} \\
\hline \multicolumn{2}{|c|}{ Other (please state): } & & [h] \\
\hline
\end{tabular}

\begin{tabular}{|l|l|l|}
\hline Q.4 & $\begin{array}{l}\text { Did you first try to obtain the item/information you requested } \\
\text { from any other source? }\end{array}$ & {$[38]$} \\
\hline Yes ................................ $\quad$ [a] \\
\hline $\begin{array}{l}\text { Where else did you try? (e.g. internet, bookshop, college/work library, not available elsewhere .... etc.) } \\
\text { Please details }\end{array}$ \\
\hline
\end{tabular}




\section{[b]}

No

Where else would or might you try? (e.g. internet, bookshop, college/work library, not available elsewhere ... etc.) Please give details

\begin{tabular}{|c|c|c|c|c|c|}
\hline Q.5 & \multicolumn{5}{|c|}{ What were the immediate effects of the item or information you requested? } \\
\hline \multicolumn{2}{|c|}{ 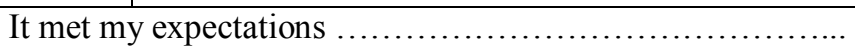 } & YES & NO & N/A & [a] \\
\hline \multicolumn{2}{|c|}{ It was suitable for the purpose it was requested } & YES & NO & N/A & {$[\mathrm{b}]$} \\
\hline \multicolumn{2}{|c|}{ It was appropriate to my existing knowledge/skills/abilities } & YES & $N O$ & N/A & [c] \\
\hline \multicolumn{2}{|c|}{ It refreshed my existing knowledge/experience............... } & YES & $N O$ & N/A & [d] \\
\hline \multicolumn{2}{|c|}{ It was partially/completely new to me $\ldots \ldots \ldots \ldots \ldots \ldots \ldots \ldots$} & YES & $N O$ & N/A & [e] \\
\hline \multicolumn{2}{|c|}{ It substantiated what I knew ................................ } & YES & NO & N/A & [f] \\
\hline \multicolumn{2}{|c|}{ I could use at least part of it immediately ...................... } & YES & NO & N/A & {$[\mathrm{g}]$} \\
\hline \multicolumn{2}{|c|}{ I will need to obtain more information/another item ......... } & YES & NO & N/A & {$[\mathrm{h}]$} \\
\hline \multicolumn{2}{|c|}{ It did not provide me with what I wanted } & YES & NO & N/A & {$[\mathrm{I}]$} \\
\hline \multicolumn{2}{|c|}{ 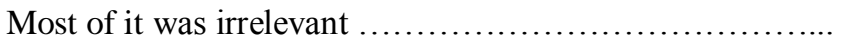 } & $Y E S$ & NO & N/A & [j] \\
\hline \multicolumn{2}{|c|}{ 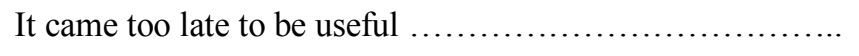 } & YES & $N O$ & N/A & {$[\mathrm{k}]$} \\
\hline
\end{tabular}

\begin{tabular}{|c|c|c|c|c|c|}
\hline $\begin{array}{l}\text { Q. } \\
6\end{array}$ & \multicolumn{3}{|c|}{$\begin{array}{l}\text { What did or might the item/information supplied by the library enable you to do? } \\
\text { Please circle YES or NO or N/A- not applicable, for each statement }\end{array}$} & & $\begin{array}{c}{[40} \\
]\end{array}$ \\
\hline \multicolumn{2}{|c|}{ Learn something new } & YES & NO & N/A & [a] \\
\hline \multicolumn{2}{|c|}{ Make a decision/choice/recommendation ................... } & YES & $N O$ & N/A & [b] \\
\hline \multicolumn{2}{|r|}{ Make progress .......................................... } & YES & NO & N/A & [c] \\
\hline \multicolumn{2}{|r|}{ 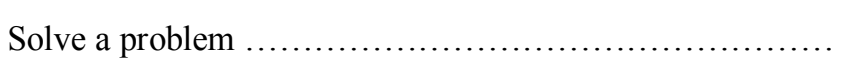 } & YES & $N O$ & N/A & [d] \\
\hline \multicolumn{2}{|c|}{ Enjoy my leisure/spare time ............................. } & YES & NO & $N / A$ & [e] \\
\hline \multicolumn{2}{|r|}{ 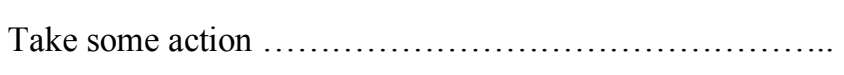 } & YES & NO & N/A & {$[\mathrm{f}]$} \\
\hline \multicolumn{2}{|c|}{ 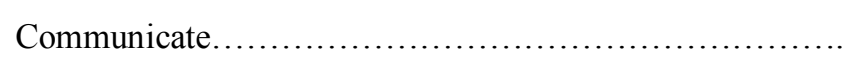 } & YES & NO & N/A & {$[\mathrm{g}]$} \\
\hline
\end{tabular}




\begin{tabular}{|c|c|c|c|c|}
\hline Participate in something... & $Y E S$ & $N O$ & $N / A$ & [h] \\
\hline Open/exploit a new opportunity ........................... & YES & $N O$ & $N / A$ & {$[\mathrm{I}]$} \\
\hline Handle an emergency . & $Y E S$ & $N O$ & $N / A$ & [j] \\
\hline Cope with/adapt to change ............ & $Y E S$ & NO & $N / A$ & {$[\mathrm{k}]$} \\
\hline Minimise some risk .................. & $Y E S$ & NO & N/A & [1] \\
\hline Take on new responsibilities .......... & $Y E S$ & $N O$ & $N / A$ & {$[\mathrm{~m}]$} \\
\hline Provided access to something ... & $Y E S$ & $N O$ & $N / A$ & [n] \\
\hline Find help/support .... & YES & $N O$ & $N / A$ & [o] \\
\hline Do business/operate a business ............... & $Y E S$ & $N O$ & $N / A$ & [p] \\
\hline Avoid conflict ........ & YES & $N O$ & N/A & [q] \\
\hline \multicolumn{4}{|c|}{ Please add further comments on what you feel use of the item/information enabled you to do: } & {$[\mathrm{r}]$} \\
\hline
\end{tabular}

\begin{tabular}{|c|c|c|c|c|c|c|c|}
\hline Q.7 & \multicolumn{6}{|c|}{$\begin{array}{l}\text { Please indicate to what extent you feel using the information or item led to a } \\
\text { change in the following } \\
\text { Please circle: where } 1 \text { represents no change and } 5 \text { represents a very }\end{array}$} & $\begin{array}{l}\frac{[41}{1} \\
1\end{array}$ \\
\hline \multicolumn{2}{|c|}{ Level of knowledge/understanding } & 1 & 2 & 3 & 4 & 5 & [a] \\
\hline \multicolumn{2}{|c|}{ Level of awareness } & 1 & 2 & 3 & 4 & 5 & [b] \\
\hline \multicolumn{2}{|c|}{ Level of skill/ability } & 1 & 2 & 3 & 4 & 5 & [c] \\
\hline \multicolumn{2}{|c|}{ Level of performance } & 1 & 2 & 3 & 4 & 5 & [d] \\
\hline \multicolumn{2}{|c|}{ Attitudes or beliefs toward something } & 1 & 2 & 3 & 4 & 5 & [e] \\
\hline \multicolumn{2}{|c|}{ Actions or behaviour } & 1 & 2 & 3 & 4 & 5 & [f] \\
\hline \multicolumn{2}{|c|}{ Health \& well-being } & 1 & 2 & 3 & 4 & 5 & {$[\mathrm{~g}]$} \\
\hline \multicolumn{2}{|c|}{ Professional opportunities/environment } & 1 & 2 & 3 & 4 & 5 & {$[\mathrm{~h}]$} \\
\hline \multicolumn{2}{|c|}{ Personal situation/environment } & 1 & 2 & 3 & 4 & 5 & {$[\mathrm{I}]$} \\
\hline \multicolumn{2}{|c|}{ Financial/Economic position or security } & 1 & 2 & 3 & 4 & 5 & [j] \\
\hline \multicolumn{2}{|c|}{ Relationships with others } & 1 & 2 & 3 & 4 & 5 & {$[\mathrm{k}]$} \\
\hline \multicolumn{2}{|c|}{ Networks/Connections } & 1 & 2 & 3 & 4 & 5 & [1] \\
\hline \multicolumn{2}{|c|}{ Personal expectations } & 1 & 2 & 3 & 4 & 5 & {$[\mathrm{~m}]$} \\
\hline \multicolumn{2}{|c|}{ Adaptability/flexibility } & 1 & 2 & 3 & 4 & 5 & {$[\mathrm{n}]$} \\
\hline \multicolumn{2}{|c|}{ Quality of life } & 1 & 2 & 3 & 4 & 5 & [o] \\
\hline
\end{tabular}




\begin{tabular}{|l|lll|l|}
\hline Q.8 & $\begin{array}{l}\text { Has using the item you requested provided ...? } \\
\text { Please circle YES or NO or N/A- not applicable, for each statement }\end{array}$ & & {$[42]$} \\
& & & & \\
\hline Stimulation & $Y E S$ & $N O$ & $N / A$ & {$[\mathrm{a}]$} \\
Inspiration & $Y E S$ & $N O$ & $N / A$ & {$[\mathrm{~b}]$} \\
Motivation & $Y E S$ & $N O$ & $N / A$ & {$[\mathrm{c}]$} \\
New experience & $Y E S$ & $N O$ & $N / A$ & {$[\mathrm{~d}]$} \\
Insight into something new & $Y E S$ & $N O$ & $N / A$ & {$[\mathrm{e}]$} \\
Sense of inclusion/ being active in something & $Y E S$ & $N O$ & $N / A$ & {$[\mathrm{f}]$} \\
Confidence & $Y E S$ & $N O$ & $N / A$ & {$[\mathrm{~g}]$} \\
Creativity & $Y E S$ & $N O$ & $N / A$ & {$[\mathrm{~h}]$} \\
Pleasure & $Y E S$ & $N O$ & $N / A$ & {$[\mathrm{I}]$} \\
Escapism/relaxation & $Y E S$ & $N O$ & $N / A$ & {$[\mathrm{j}]$} \\
A sense of achievement & $Y E S$ & $N O$ & $N / A$ & {$[\mathrm{k}]$} \\
A sense of security & $Y E S$ & $N O$ & $N / A$ & {$[\mathrm{l}]$} \\
Broadened your horizons & $Y E S$ & $N O$ & $N / A$ & {$[\mathrm{~m}]$} \\
A sense of identity & $Y E S$ & $N O$ & $N / A$ & {$[\mathrm{n}]$} \\
Frustration/anger & $Y E S$ & $N O$ & $N / A$ & {$[\mathrm{o}]$} \\
Uncertainty & $Y E S$ & $N O$ & $N / A$ & {$[\mathrm{p}]$} \\
\hline Please add further comments what you felt through using the item/information & & & {$[\mathrm{q}]$} \\
\hline & & & & \\
& & & & \\
& & & & \\
\hline
\end{tabular}

\begin{tabular}{|c|c|c|c|}
\hline$\underline{Q .9 a}$ & $\begin{array}{l}\text { Will the results of using the item supplie } \\
\text { shared with anyone other than yourself? } \\
\text { Please tick. }\end{array}$ & y the library be felt by or & [43] \\
\hline \multicolumn{4}{|c|}{ Yes (seeQ.9b) } \\
\hline$Q .9 b$ & $\begin{array}{l}\text { If yes, with whom will they be shared? } \\
\text { (e.g. an organisation, colleagues, friends o }\end{array}$ & mily, a social or community group etc.) & [44] \\
\hline$\underline{Q .9 c}$ & $\begin{array}{l}\text { If yes, how will they be shared? } \\
\text { (e.g. formal report/presentation/negotiatio }\end{array}$ & formal chat/discussion, publication etc.) & [45] \\
\hline
\end{tabular}




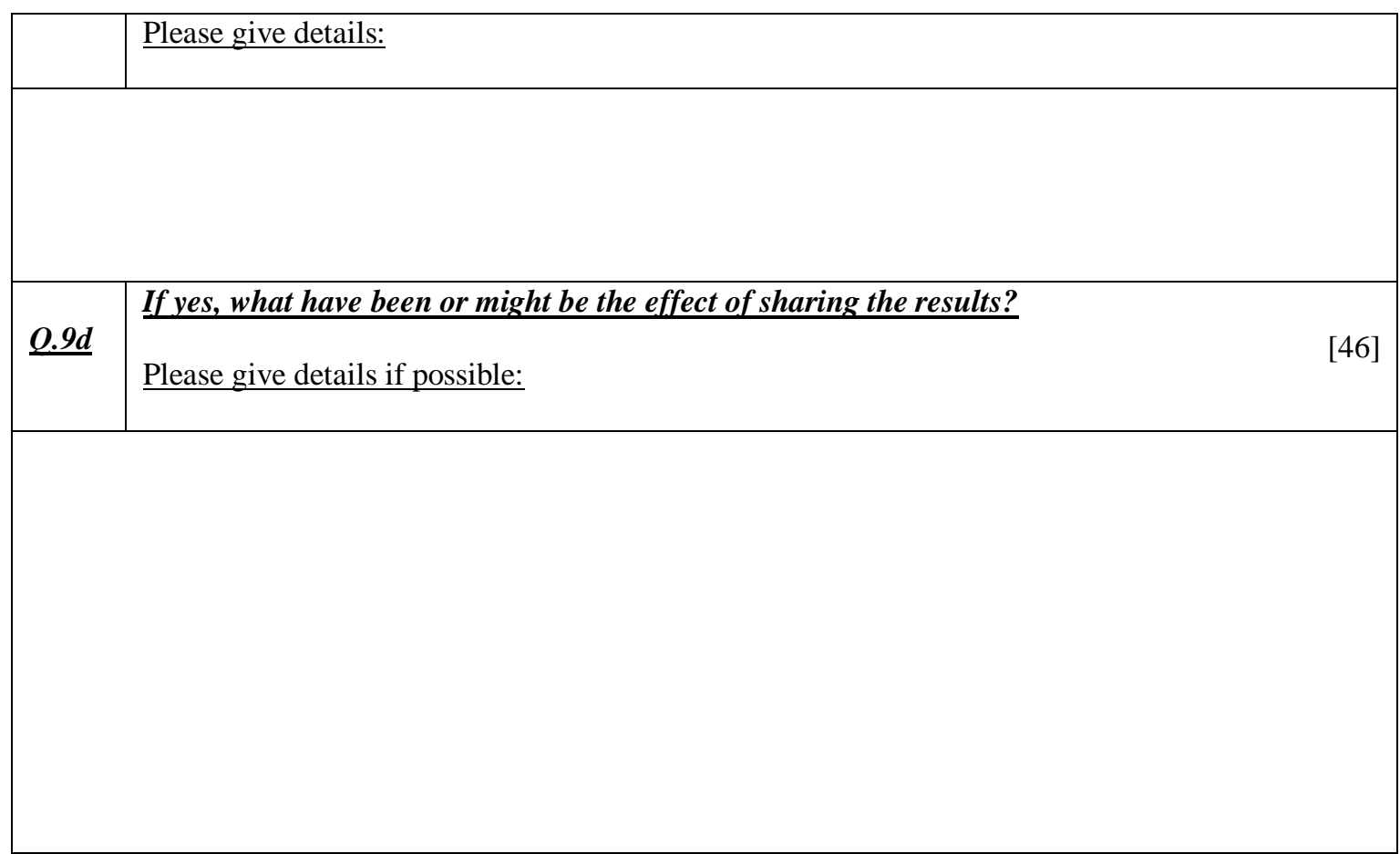

\begin{tabular}{|l|l|l|}
\hline Q.10 & $\begin{array}{l}\text { Were there any barriers or considerations that prevented you from using the item } \\
\text { to the degree you needed? } \\
\text { (Please state) }\end{array}$ & $\mid$ \\
\hline \\
\hline
\end{tabular}

Thank you for completing this questionnaire. Please return it in the stamped addressed envelope provided before $1^{\text {st }}$ June 2007.

If you would like to take part in the optional follow-up telephone survey please complete the consent form included in the survey pack and return it along with your completed questionnaire. 